\title{
Pivotal Influence of Chemical Inducers on Antioxidant Enzyme Activities and Barley Yield under Biotic and Abiotic Stresses
}

\author{
E.M. Hafez ${ }^{\#}$ and Y.M. Hafez ${ }^{*}$ \\ Agronomy Dept. and "EPCRS Excellence Center, Agricultural \\ Botany Dept., Plant Pathology section, Faculty of Agriculture, \\ Kafrelsheikh University, 33516, Kafrelsheikh, Egypt.
}

\begin{abstract}
7 HE OBJECTIVE of this research was to determine the effect of .....chemical inducers on leaf area index, chlorophyll content, relative water content and yield characters, antioxidant enzyme activities and disease severity in barley plants under biotic (Blumeria graminis f.sp. hordei (Bgh) and abiotic (water deficit) stresses. This study was carried out at the Experimental Farm of Faculty of Agriculture, Kafrelsheikh University using water treatments (water deficit by two irrigations and well-watered by five irrigations) and four treatments of chemical inducers including control, salicylic acid (SA),oxalic acid (OXA) and Benzothiadiazole (BTH) in the rate of untreated plants, $200 \mathrm{mg} \mathrm{L}^{-1}, 1 \mathrm{~g} \mathrm{~L}^{-1}$ and $0.9 \mathrm{mM} \mathrm{L}^{-1}$, respectively. Water deficit appreciably decreased significantly almost all the studied parameters compared with well-watered treatment. However, chemical inducers application improved all the studied parameters under water deficit. Activity of antioxidant enzymes (catalase and peroxidase) showed significant increases in plants treated with chemical inducers under water deficit. Chemical inducers have been found effective in mitigating the negative effects of water deficit and disease severity in both seasons. SA was increased almost all the studied parameters in both seasons more than OXA and BTH. These results indicated that chemical inducers (SA, OXA and BTH) are convenient and could be recommended to increase the productivity and resistance the adverse conditions.
\end{abstract}

Keywords: Salicylic acid, Oxalic acid, Benzothiadiazole, Antioxidant enzymes, Water deficit.

Barley (Hordeum vulgare L.) is the fourth crop among the major cereal grains in terms of World and Egyptian production after wheat, rice and maize. Barley is playing a major role in bread making with wheat and used as animal feeding. In Egypt, barley can replace wheat as the dominant crop in the North Coastal Region and also in the newly reclaimed lands with water deficit due to its tolerant to abiotic stress (El-Seidy et al., 2013). Barley among cereal crops is tolerance under moderate adverse environmental conditions. Thus, barley plants are useful in Egypt due to limiting water supply. Stability of economical yield under water deficit is very necessary, which can be achieved by novel mechanisms.

${ }^{\#}$ Corresponding author: Dr. Emad Hafez (emadhafez2014@gmail.com) 
Water deficit is regarded as one of the most unpredictable and inevitable abiotic stresses and one of the most important obstacles that exhibited in many regions of the world especially in Egypt and is expected to increase in the future (Fayez \& Bazaid, 2014). Water deficit leads to reduction in shoot growth, leaf area and biomass of barley plants (Fayez \& Bazaid, 2014 and Hafez et al., 2015). In addition, water deficit diminishes plant metabolic processes including relative water content, nutrient absorption and chlorophyll content (Cossania et al., 2012; Ahmed et al., 2013 and Hafez et al., 2014b). With increment of water deficit, barley productivity is affected greatly (Krček et al., 2008; Cossania et al., 2012 and Hafez \& Abou El-Hassan, 2015). Antioxidant benefit in cereals has been believed to be one of the main physiological mechanisms and be pivotal in relation to water deficit (Cossania et al., 2012). The imposition of water deficit can result in excessive contents of reactive oxygen species (Hafez \& Gharib, 2016).

The control of plant diseases is carried out usually by fungicide treatments; however, the application of fungicides is limited because of the development of pathogenic strains with fungicide resistance, the action on human health and the environment (Hafez et al., 2014a). Using of alternative control treatments such as salicylic acid, oxalic acid and benzothiadiazole (BTH) seem important (Hafez et al., 2014a).

Plants which include high activity of antioxidant enzymes have shown appreciable tolerance to oxidative damage caused by reactive oxygen species resulting from water deficit (Omwamba et al., 2013) as abiotic stress as well as biotic stresses (Hafez et al., 2012). Exogenous application by chemical inducers have a crucial role in scavenging free radicals and reduce the negative impacts of increased reactive oxygen species resulting in water deficit (Anjum et al., 2011).

Exogenous application of salicylic acid (SA) and oxalic acid (OXA) were effective in the regulation of biotic, abiotic stresses and physiological processes (Gunes et al., 2007 and induce resistance in plants due to antioxidant capability (Zheng et al., 1999 and Malencic et al., 2004). Benzothiadiazole (BTH) is a chemical inducer of tolerance and a functional analogue to SA (Görlach et al., 1996). The synthetic chemical benzothiadiazole (BTH) was also demonstrated to be a potent SAR activator (Görlach et al., 1996 and Lawton et al. 1996) that supplies protection in the field against some biotic and abiotic stresses in several crops. Thus, BTH seems to be proper compounds for practical agronomic use (Hafez et al., 2012 and Hafez et al., 2014a).

Although numerous studies have previously carried out to study the relation of barley to water deficit, nonetheless, a little information is available concerning role of exogenous application of salicylic acid, oxalic acid and BTH on economic yield of barley and activity of antioxidant enzymes under water deficit. Thus, the ultimate objective of our current study is to assess whether salicylic acid, oxalic acid and BTH may ameliorate the passive impacts of water deficit stress on barley through monitoring yield components and physiological Egypt. J. Agron. 38, No. 2 (2016) 
characters as well as changes the activity of antioxidant enzymes which play a pivotal role in resistance and improve the yield characters.

\section{Materials and Methods}

\section{Plant materials}

This study was carried out at the Experimental Farm of the Faculty of Agriculture, Kafrelsheikh University, Egypt $\left(31^{\circ} 05^{\prime} 54.3^{\prime \prime N}\right.$, 30 $\left.57^{\circ} 19.4^{\prime \prime E}\right)$ during two successive growing seasons in 2012-2013 and 2013-2014, respectively. Climatical data (Table 1) were collected from an agrometeorological Sakha Station located $2 \mathrm{~km}$ from the Experimental site. Soil samples were taken using a soil Auger to analyze $\mathrm{N}$ content by Kjeldahl method (Bremner, 1960). The soil was clayey and an average bulk density of $1.22 \mathrm{~g}$ $\mathrm{cm}^{-3}$. The soil contained $1.37 \%$ total organic matter, 0.15 and $0.17 \%$ total nitrogen $(\mathrm{N}), 35$ and $38 \mathrm{mg} \mathrm{kg}^{-1}$ available phosphorus $(\mathrm{P})$ and 255.3 and 261.5 $\mathrm{mg} \mathrm{kg}^{-1}$ exchangeable potassium (K), EC 1.05 and $1.13 \mathrm{ds} \mathrm{m}^{-1}(1: 5), \mathrm{pH} 8.1$ and $8.05(1: 2.5), 1.38$ and $1.45 \mathrm{~cm}$ annual precipitation in 2012-2013 and 2013-2014 seasons, respectively.

TABLE 1. Monthly relative humidity $(\mathrm{RH}, \%)$, wind speed $\left(\mathrm{km} \mathrm{day}^{-1}\right)$, mean maximum and minimum air temperatures (Tmax and Tmin, respectively) during the two winter growing seasons.

\begin{tabular}{|c|c|c|c|c|c|c|c|c|}
\hline \multirow{3}{*}{$\begin{array}{l}\text { Season } \\
\text { Month }\end{array}$} & \multicolumn{4}{|c|}{$2012 / 2013$} & \multicolumn{4}{|c|}{$2013 / 2014$} \\
\hline & \multicolumn{2}{|c|}{$\begin{array}{c}\text { Temperature } \\
\text { (C) }\end{array}$} & \multirow{2}{*}{$\begin{array}{c}\text { Wind } \\
\text { speed } \\
\left(\mathbf{k m ~ d a y ~}^{-1}\right)\end{array}$} & \multirow[t]{2}{*}{$\begin{array}{l}\text { RH } \\
(\%)\end{array}$} & \multicolumn{2}{|c|}{$\begin{array}{l}\text { Temperature } \\
\text { (C) }\end{array}$} & \multirow{2}{*}{$\begin{array}{c}\text { Wind } \\
\text { speed } \\
\left(\mathrm{km} \mathrm{day}^{-1}\right)\end{array}$} & \multirow[t]{2}{*}{$\begin{array}{l}\text { RH } \\
(\%)\end{array}$} \\
\hline & Tmax & Tmin & & & Tmax & Tmin & & \\
\hline Dec. & 17.7 & $\overline{11.6}$ & 155.5 & 37.8 & 16.9 & 11.4 & 156.0 & 30.7 \\
\hline Jan. & 22.6 & 11.0 & 158.7 & 41.4 & 23.5 & 9.4 & 142.0 & 41.4 \\
\hline Feb. & 23.3 & 11.9 & 167.9 & 45.5 & 22.0 & 11.0 & 152.1 & 45.1 \\
\hline Mar. & 22.5 & 14.7 & 129.3 & 49.2 & 24.0 & 16.2 & 123.5 & 47.9 \\
\hline April & 29.1 & 17.0 & 89.1 & 52.5 & 27.4 & 17.2 & 88.2 & 55.4 \\
\hline May & 33.8 & 18.2 & 111.7 & 61.1 & 31.9 & 17.8 & 96.3 & 64.1 \\
\hline
\end{tabular}

max $=$ maximum, min $=$ minimum, $R H=$ relative humidity

\section{Experimental design and agronomic practices}

The experiment was laid out as a split- plot arrangement with three replicates. Two water treatments including (water deficit and well-watered) were assigned in main plots and separated well to avoid infiltration when water treatments were applied. Four treatments of chemical inducers including (control, benzothiadiazole (BTH), oxalic acid and salicylic acid) were allocated to the subplots. The preceding crop was Maize (Zea mays L.) during the growing seasons. Calcium superphosphate $\left(15.5 \% \mathrm{P}_{2} \mathrm{O}_{5}\right)$ was added at the rate of $125 \mathrm{~kg}$ $\mathrm{ha}^{-1}$ during seedbed preparation. The amount of $\mathrm{N}$ fertilizer applied was $110 \mathrm{~kg} \mathrm{~N}$ $\mathrm{ha}^{-1}$ as ammonium sulphate $(20.6 \% \mathrm{~N})$ to each plot at two doses; $40 \%$ before first irrigation and $60 \%$ before second irrigation.

Water deficit was achieved after two irrigations (sowing and tillering stages) by withholding the water supply at the end of the tillering stage till physiological maturity. Meanwhile, well-watered was achieved by the water supply for five 
irrigations (sowing, tillering, stem elongation, booting and reproductive stages). Salicylic acid (SA), oxalic acid (OX) and benzothiadiazole (BTH), respectively at concentrate of $200 \mathrm{mg} \mathrm{L}^{-1}, 1 \mathrm{~g} \mathrm{~L}^{-1}$ and $0.9 \mathrm{mM} \mathrm{L}^{-1}$, were sprayed during the vegetative growth stage, at 60 and at 75 days after sowing (DAS).

Barley (Hordium vulgare L., Cv. Giza 123) is originated in Barley Department, Field Crops Research Institute, Agricultural Research Centre, Ministry of Agriculture, Giza, Egypt, was planted on December $7^{\text {th }}$ during 2012/2013 and December $1^{\text {st }}$ during $2013 / 2014$ at a row spacing of $12.5 \mathrm{~cm}$ and a seeding rate of $120 \mathrm{~kg} \mathrm{ha}^{-1}$. Weeds were controlled by Topik 15\% WP herbicide and mechanical control. The experimental unit size (plot) was $10.5 \mathrm{~m}^{2}$ (3 m width x $3.5 \mathrm{~m}$ long). Barley grain yield (14\% moisture) obtained by harvesting the center ( $2 \mathrm{~m} \times 2 \mathrm{~m}$ ) of the plot, but yield components were determined from two outer rows within each plot.

Morphological and physiological measurements

Leaf area index $\left(\mathrm{cm}^{2}\right)$ measurement and chlorophyll content (SPAD)

From each plot, a sub-sample for the measurement of leaf area by Leaf Area Meter (Li-Cor 3100, Lambda Instruments Co., USA).

Hand-held chlorophyll meter (SPAD-502; Minolta Sensing Co., Ltd, Japan) was used to record SPAD readings from the topmost fully expanded leaves on each main stem at heading stage. SPAD values were measured at three different points along the flag leaf blade, and then the readings were averaged to have a single value for a plant (Markwell et al., 1995).

\section{Leaf relative water content}

Relative water content was estimated using fully expanded leaves, weighted for fresh weight (FW). Turgid weight (TW) was determined after the leaves were rehydrated in distilled water into a closed container at $10^{\circ} \mathrm{C}$ in the dark for $24 \mathrm{~h}$ and weighted again. Dry weight (DW) was determined for the same leaves after oven-drying for 3 days at $80^{\circ} \mathrm{C}$. RWC was calculated using the following equation: $\mathrm{RWC}(\%)=[(\mathrm{FW}-\mathrm{DW}) /(\mathrm{TW}-\mathrm{DW})] \times 100($ Jeon et al., 2006) .

\section{Biochemical assays of antioxidant enzymes}

The tested antioxidant enzyme activities were measured in plants, $0.5 \mathrm{~g}$ leaf

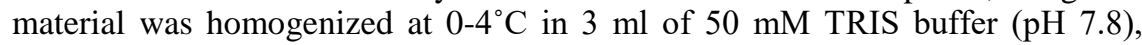
containing $1 \mathrm{mM}$ EDTA-Na2 and $7.5 \%$ polyvinylpyrrolidone. The homogenates were centrifuged $\left(12,000 \mathrm{rpm}, 20 \mathrm{~min}, 4^{\circ} \mathrm{C}\right)$, and the total soluble enzyme activities were measured spectrophotometrically in the supernatant (Hafez et al., 2012). All measurements were carried out at $25^{\circ} \mathrm{C}$, using the model UV-160A spectrophotometer (Shimadzu, Japan).

Activity of catalase (CAT) was determined spectrophotometrically according to (Aebi, 1983). Changes in the absorbance at $240 \mathrm{~nm}$ were recorded every 30 sec intervals for 3 min. Enzyme activity was expressed as the increase in absorbance $\min ^{-1} \mathrm{~g}^{-1}$ fresh weight. Activity of guaiacol peroxidase (POX) activity was directly determined of the crude enzyme extract according to a typical procedure proposed by Hammerschmidt et al. (1982). Changes in Egypt. J. Agron. 38, No. 2 (2016) 
absorbance at $470 \mathrm{~nm}$ were recorded every $30 \mathrm{sec}$ intervals for $3 \mathrm{~min}$. Enzyme activity was expressed as the increase in absorbance $\min ^{-1} \mathrm{~g}^{-1}$ fresh weight.

\section{Yield components}

After harvest the biological yield and the yield components (number of grains spike $^{-1}$, number of spikes $\mathrm{m}^{-1}$ and 1000-grain weight) were determined for all plots. The harvest dates at maturity were $2^{\text {nd }}$ May 2013 and $7^{\text {th }}$ May 2014. Plant samples collected at harvest were separated into grain and straw and electric oven-dried at $70^{\circ} \mathrm{C}$ for $72 \mathrm{~h}$ till constant dry weight, then were grounded in a mill to produce a fine powder which is needed for the $\mathrm{N}$ analysis using the standard procedure of micro-Kjeldahl digestion with Sulfuric acid. Wheat grain protein content was obtained by multiplying grain $\mathrm{N}$ content (\%) by 5.75 (A.O.A.C., 1980).

\section{Fungal inoculation}

Natural infection of Blumeria graminis f.sp. hordei (Bgh) conidia, the causal of barley powdery mildew, were conducted under field condition. Plant spreaders (susceptible host) were uniformly inoculated with freshly collected conidiospores by placing heavy infected plants of barley which sensitive to $B g h$ inoculation.

\section{Disease severity assay}

Ten plants of each treatment were scored visually for percentage of leaf area covered by powdery mildew on a 0 (resistant) to 10 (susceptible) scale 10 days after spraying of chemical inducers in each experiment. For analysis, disease scores were converted using the modified logarithmic scale of Horsfall-Barrett (Horsfall \& Cowling, 1978). The scale was $0=0 \%, 1=0-3 \%, 2=+3-6 \%, 3=$ $+6-12 \%, 4=+12-25 \%, 5=+25-50 \%, 6=+50-75 \%, 7=+75-88 \%, 8=$ $+88-94 \%, 9=+94-97 \%$ and $10=+97-100 \%$. Disease severity index (DSI) was calculated according to Kim et al. (2000) using the following formula:

$$
\text { DSI }=\frac{\sum \text { Ratings of each plant }}{10 \times \text { Number of plants rated }} \times 100
$$

Statistical analysis

Data obtained were subjected to an analysis of variance (ANOVA) procedures according to Gomez \& Gomez (1984) using the MSTAT-C Statistical Software package. Different Means were compared using Duncan (1955), when the ANOVA showed significant differences $(\mathrm{P}<0.05)$.

\section{Results and Discussions}

Effect of treatments on leaf area index, chlorophyll content and relative water content at heading stage

Water deficit posed negative effects on leaf area index, chlorophyll content and relative water content in both seasons compared with well-watered treatment. Nonetheless, chemical inducers application increased leaf area index, chlorophyll content and relative water content in water deficit (Fig. 1). Water deficit led to loss of turgor pressure in the leaves which result in closeness of the pores and decreased of photo-assimilates during limited water supply (WU et al., 
2008 and Hafez \& Kobata, 2012). Low relative water content could be due to a reduction of water supply to the leaves (Ghotbi-Ravandi et al., 2014). Some authors demonstrated that negative impacts of water stress on stomata closure and photosynthesis rate led to decline leaf area and chlorophyll content (GhotbiRavandi et al., 2014).
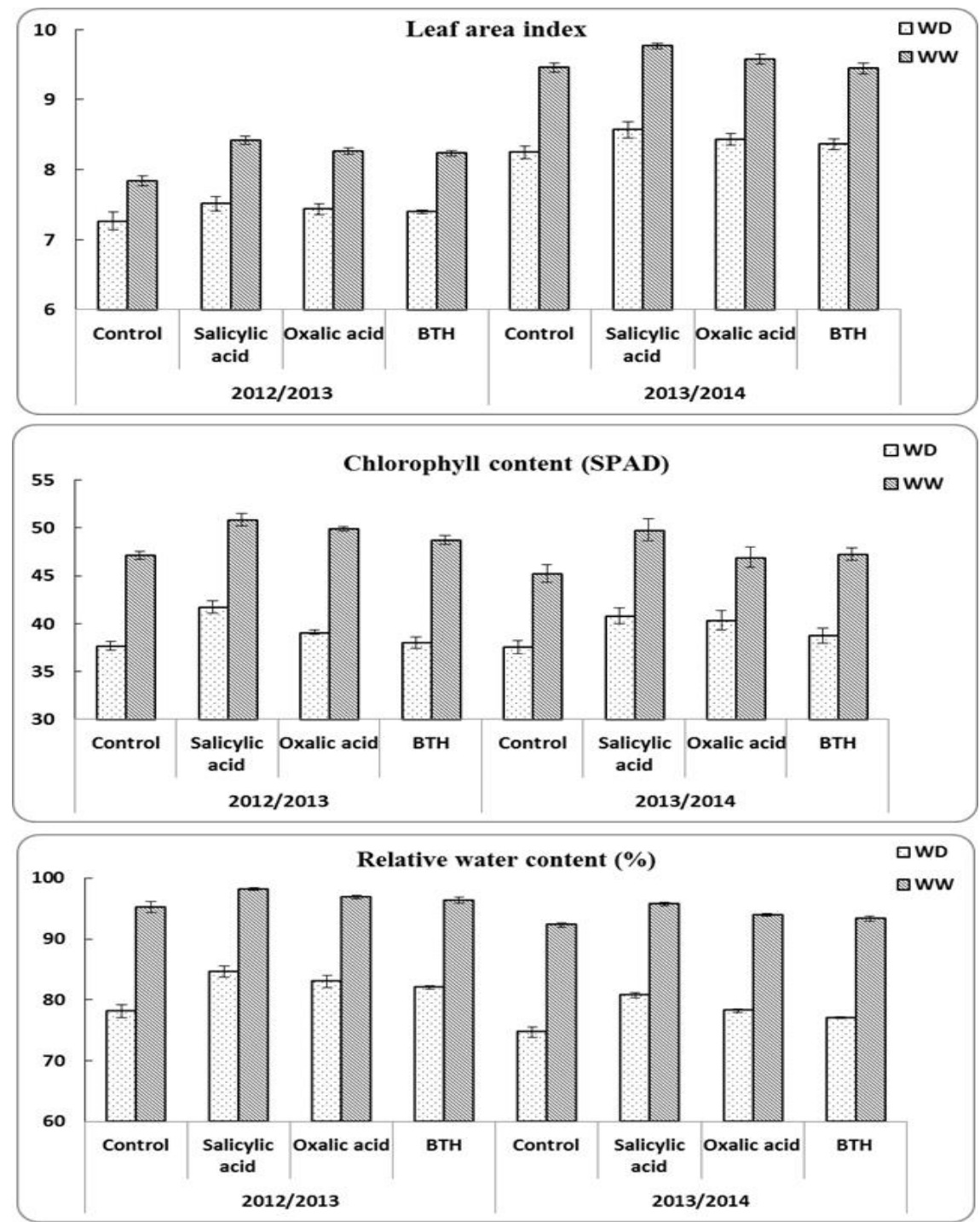

Fig. 1. Effect of water treatments (WW and WD) and chemical inducers (control, salicylic acid, oxalic acid and BTH) on leaf area index, relative water content and chlorophyll content at heading stage in 2012/2013 and 2013/2014 seasons. Data are the mean \pm SE of three replicates. WD: water deficit, WW: wellwatered.

Egypt. J. Agron. 38, No. 2 (2016) 
Among chemical inducers application, it was found that exogenously supplied salicylic acid caused relatively higher leaf area index, chlorophyll content and relative water content which could alleviate negative effects of water deficit by increasing the levels of antioxidant enzymes (Hafez et al., 2012 and Hafez et al., 2014). In addition, it might be attributed to lower the osmotic potential, which might help to preserve the metabolic processes, and contribute to plant growth by preserving cell turgor, as well regulating cell growth and division (Pirasteh-Anosheh et al., 2015).

\section{Effect of treatments on the disease severity (\%)}

Disease symptoms were first found at the end of February 2012-2013 and the first week of March in 2013-2014. Chemical inducers significantly reduced disease's severity and symptoms as well. Treatments of salicylic acid, oxalic acid and BTH decreased the number of leaves infected with powdery mildew compared to control treatment. Efficacy of the tested treatments to decrease the severity was increased under water deficit by BTH (15 and $25 \%$, respectively in the growing seasons) which ranked the first at both seasons, followed by salicylic acid (40 and $50 \%$, respectively in the growing seasons) and oxalic acid (40 and 55\%, respectively in the growing seasons) relatively, compared to control treatment (57 and $60 \%$, respectively in the growing seasons) (Fig. 2). While, Efficacy of the tested treatments to decrease the severity was a slightly more increased under well-watered by BTH (15 and $20 \%$, respectively in the growing seasons) which ranked the first at both seasons, followed by salicylic acid (35 and $45 \%$, respectively in the growing seasons) and oxalic acid (36 and 44\%, respectively in the growing seasons) relatively, compared to control treatment (50 and $55 \%$, respectively in the growing seasons) (Fig. 2). Disease severity was the lowest in case of BTH; it could be due to the highest POX activity (Fig. 3). As a result of this induction of ROS, disease severity and symptoms were suppressed (Fig. 2), this could be due to the inhibiting or the killing action of ROS to the fungal pathogen after spraying, therefore, no opportunity for the pathogen to grow or multiply (Hafez et al., 2014).

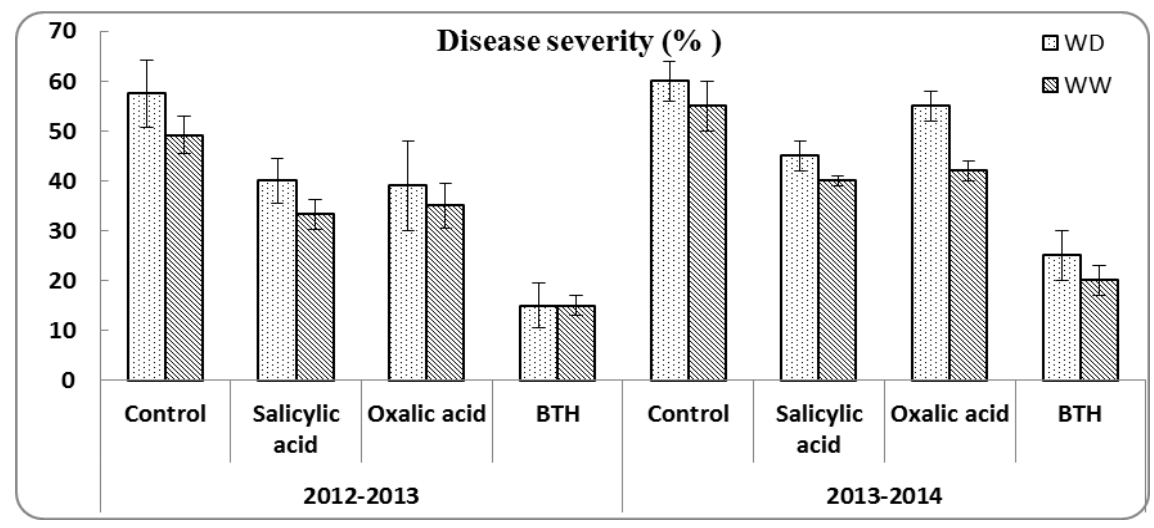

Fig. 2. Effect of water treatments (WW and WD) and chemical inducers (control, salicylic acid, oxalic acid and BTH) on disease severity (\%) in 2012/2013 (S1) and 2013/2014 (S2) seasons. The data are the mean $\pm \mathrm{SE}$ of three replicates. WD: water deficit, WW: well-watered. 


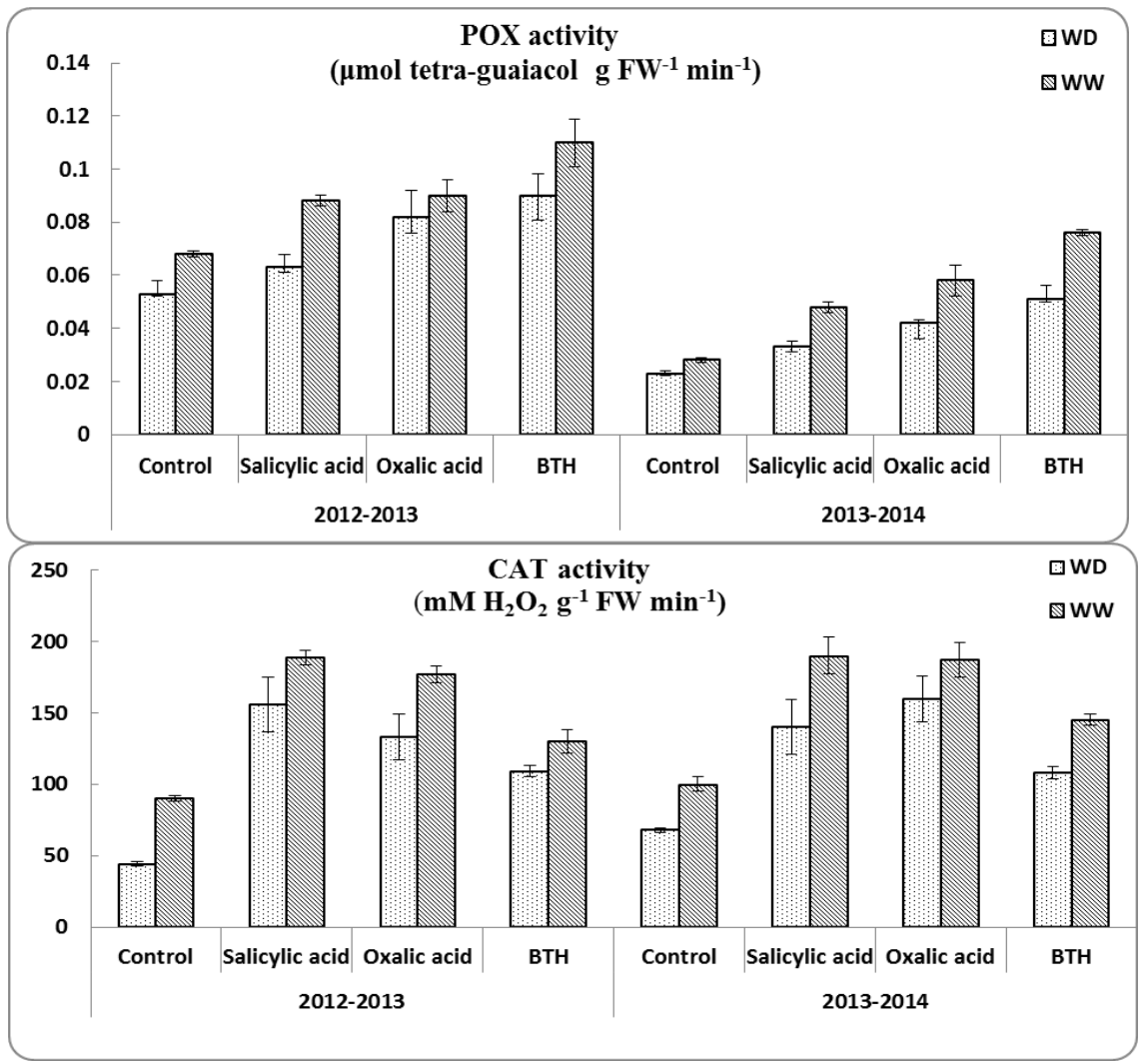

Fig. 3. Effect of water treatments (WW and WD) and chemical inducers (control, salicylic acid, oxalic acid and BTH) on CAT and POX activities at heading stage in 2012/2013 and 2013/2014 seasons. The data are the mean $\pm \mathrm{SE}$ of three replicates. WD: water deficit, WW: well-watered.

Effect of treatments on activity of antioxidant enzymes

Data presented in Fig. 3 showed the average of antioxidant enzyme activities (CAT and POX) in the leaf extracts of barley plants under water deficit and wellwatered conditions in both growing seasons. Activities of CAT and POX in leaves for Giza 123 were significantly enhanced and markedly increased during the growing seasons under water deficit and well watered treatments by exogenous application of chemical inducers.

In the case of foliar spray under water deficit, it was observed that salicylic acid led to increase in CAT activity more than oxalic acid and BTH compared to untreated plants in 2012-2013 season. Whereas, salicylic acid was increased CAT activity to $160 \mathrm{mM} \mathrm{H}_{2} \mathrm{O}_{2} \mathrm{~g}^{-1} \mathrm{FW} \min ^{-1}$ in addition to oxalic acid was increased CAT activity to $140 \mathrm{mM} \mathrm{H}_{2} \mathrm{O}_{2} \mathrm{~g}^{-1} \mathrm{FW} \mathrm{min}^{-1}$ as well as BTH was increased CAT activity to $120 \mathrm{mM} \mathrm{H}_{2} \mathrm{O}_{2} \mathrm{~g}^{-1} \mathrm{FW} \mathrm{min}{ }^{-1}$ compared to untreated plants whereas CAT activity was low $40 \mathrm{mM} \mathrm{H}_{2} \mathrm{O}_{2} \mathrm{~g}^{-1} \mathrm{FW} \mathrm{min}{ }^{-1}$ under water deficit and $90 \mathrm{mM} \mathrm{H}_{2} \mathrm{O}_{2} \mathrm{~g}^{-1} \mathrm{FW} \mathrm{min}{ }^{-1}$ under well-watered in the first season. In

Egypt. J. Agron. 38, No. 2 (2016) 
the second season was almost the same, oxalic acid led to increase of CAT activity more than salicylic acid and BTH compared to untreated plants. Whereas oxalic acid was increased CAT activity to $160 \mathrm{mM} \mathrm{H}_{2} \mathrm{O}_{2} \mathrm{~g}^{-1} \mathrm{FW} \mathrm{min}^{-1}$ in addition to salicylic acid was increased CAT activity to $150 \mathrm{mM} \mathrm{H}_{2} \mathrm{O}_{2} \mathrm{~g}^{-1} \mathrm{FW}$ $\mathrm{min}^{-1}$ as well as BTH was increased CAT activity to $120 \mathrm{mM} \mathrm{H}_{2} \mathrm{O}_{2} \mathrm{~g}^{-1} \mathrm{FW} \mathrm{min}{ }^{-1}$ compared to untreated plants. Whereas, CAT activity was low $70 \mathrm{mM} \mathrm{H} \mathrm{H}_{2} \mathrm{O}_{2} \mathrm{~g}^{-1}$ FW $\min ^{-1}$ under water deficit and $100 \mathrm{mM} \mathrm{H}_{2} \mathrm{O}_{2} \mathrm{~g}^{-1} \mathrm{FW} \mathrm{min}{ }^{-1}$ under wellwatered (Fig. 3).

In the case of foliar spray under water deficit, it was observed that BTH increased POX activity more than oxalic acid and salicylic acid compared to untreated plants in 2012-2013 and 2013-2014 seasons. Whereas BTH was increased POX activity to 0.09 and $0.07 \mu \mathrm{mol}$ tetra-guaiacol $\mathrm{g} \mathrm{FW}^{-1} \mathrm{~min}^{-1}$, respectively in 2012-2013 and 2013-2014 seasons, in addition to oxalic acid was increased POX activity to 0.08 and $0.06 \mu \mathrm{mol}$ tetra-guaiacol $\mathrm{g} \mathrm{FW}^{-1} \mathrm{~min}^{-1}$ in 2012-2013 and 2013-2014 seasons, respectively as well as salicylic acid was increased POX activity to 0.07 and $0.05 \mu \mathrm{mol}$ tetra-guaiacol $\mathrm{g} \mathrm{FW}^{-1} \mathrm{~min}^{-1}$ in 2012-2013 and 2013-2014 seasons, respectively compared to untreated plants whereas POX activity was low 0.05 and $0.02 \mu \mathrm{mol}$ tetra-guaiacol $\mathrm{g} \mathrm{FW}^{-1} \mathrm{~min}^{-1}$ in 2012-2013 and 2013-2014 seasons, respectively under water deficit and 0.07 and $0.03 \mu \mathrm{mol}$ tetra-guaiacol $\mathrm{g} \mathrm{FW}^{-1} \mathrm{~min}^{-1}$ under well-watered in 2012-2013 and 2013-2014 seasons, respectively (Fig. 3).

In the current research, activities of antioxidant enzymes (CAT and POX) in barley plants were increased under water deficit as well as after exogenous application by chemical inducers. These higher contents of antioxidant enzymes might be due to high defense capability. As well as their characteristics which help the plant's resistance against oxidative damage and increased the resistance against the powdery mildew and were able to decrease the disease severity (Hafez et al., 2012). Harb et al. (2015) stated an increase in antioxidant enzyme activities in barley plants after salicylic acid application. Noctor et al. (2014) pointed out that an increase in the activity of antioxidant enzymes helps the plants to conserve their growth under water deficit which may be considered as an indicator of water deficit resistance. The high activities of enzymatic antioxidants neutralized the harmful effects of ROS (oxidative stress). Particularly, $\mathrm{H}_{2} \mathrm{O}_{2}$ seems to play a dual role by eliciting localized death of plant and pathogen cells and as a diffusible signal for the induction of antioxidant and pathogenesis-related genes in adjacent plant tissues (Hafez et al., 2012).

\section{Effect of treatments on yield characters}

The current research investigated the effect of exogenous spraying of some chemical inducers on the antioxidant enzymes activity and yield productivity as well as disease severity of barley (Giza 123 cultivar) subjected to water deficit. From these results, the data showed that water deficit considerably reduced the yield characters in terms of 1000-grain weight, number of grains spike ${ }^{-1}$, number of spikes $\mathrm{m}^{-2}$, grain yield, straw yield and harvest index (Tables 2, 3). However, better yield characters were observed under well-watered treatment. Chemical 
inducers application enhanced the yield characters by improving 1000-grain weight, number of grains spike ${ }^{-1}$, number of spikes $\mathrm{m}^{-2}$, yield productivity (grain and straw yields) and harvest index under water treatments in 2012/2013 and 2013-2014 growing seasons (Tables 2, 3). Among chemical inducers application, it was observed in this study that salicylic acid performed relatively better compared to oxalic acid and BTH in all yield characters above mentioned under both water treatments in the growing seasons (Tables 2,3). Salicylic acid ranked the first, followed by oxalic acid and BTH in both seasons. On average of both growing seasons, the effect of salicylic acid was to increase 1000-grain weight $(+8.2 \%)$, number of grains spike ${ }^{-1}(+10.4 \%)$, number of spikes $\mathrm{m}^{-2}(+5.1 \%)$, grain yield $(+12.3 \%)$, straw yield $(+7.6 \%)$, harvest index $(+6.4 \%)$. Yield characters and productivity of barley under water deficit might be due to low water supply for photosynthesis, which led to reduced yield characters and productivity (Samarah, 2005). Furthermore, it might also be ascribed to fewer uptakes of moisture and nutrients from soil and thus affected cell division and differentiation with concomitant decline in 1000-grain weight, number of grains spike $^{-1}$ and number of spikes $\mathrm{m}^{-2}$ (Pecio \& Wach, 2015). Application of chemical inducers was beneficial in alleviating the passive impacts of water deficit. These results are in agreement with previous studies which reported that salicylic acid application (Bandurska and Stroinski 2005) and oxalic acid as well as BTH (Hafez et al., 2014a) enhanced the plant tolerance to water deficit by utilizing the soil water more efficiently as compare to control treatment by increasing levels of ABA and proline which act in closing the stomata and help lower the osmotic potential of the plant.

TABLE 2. Effect of water treatments, chemical inducers on 1000-grain weight, number of grains spike ${ }^{-1}$ and number of spikes $\mathrm{m}^{-2}$, respectively in 2012/2013 and 2013/2014 seasons.

\begin{tabular}{|l|c|c|c|c|c|c|}
\hline \multicolumn{1}{|c|}{ Treatments } & \multicolumn{2}{c|}{$\begin{array}{c}\text { 1000-grain weight } \\
\text { (g) }\end{array}$} & \multicolumn{2}{c|}{ No. grains spike } & \multicolumn{2}{c|}{ No. spikes m-2 } \\
\hline Water treatments (W) & S1 & S2 & S1 & S2 & S1 & S2 \\
\hline WD & $40.73 \mathrm{~b}$ & $41.73 \mathrm{~b}$ & $23.25 \mathrm{~b}$ & $24.35 \mathrm{~b}$ & $\begin{array}{c}307.92 \\
\mathrm{~b}\end{array}$ & $310.66 \mathrm{~b}$ \\
\hline WW & $43.65 \mathrm{a}$ & $44.74 \mathrm{a}$ & $25.33 \mathrm{a}$ & $25.72 \mathrm{a}$ & $319.42 \mathrm{a}$ & $316.25 \mathrm{a}$ \\
\hline Chemical inducers (C) & \multicolumn{7}{|l|}{} \\
\hline Control & $40.49 \mathrm{c}$ & $43.47 \mathrm{~d}$ & $23.00 \mathrm{~b}$ & $25.62 \mathrm{c}$ & $\begin{array}{c}307.17 \\
\mathrm{~b}\end{array}$ & $315.33 \mathrm{~b}$ \\
\hline SA & $43.93 \mathrm{a}$ & $46.57 \mathrm{a}$ & $25.33 \mathrm{a}$ & $27.66 \mathrm{a}$ & $318.00 \mathrm{a}$ & $318.65 \mathrm{a}$ \\
\hline OX & $42.29 \mathrm{~b}$ & $44.28 \mathrm{~b}$ & $\begin{array}{c}24.50 \\
\mathrm{ab}\end{array}$ & $27.00 \mathrm{ab}$ & $315.00 \mathrm{a}$ & $315.26 \mathrm{ab}$ \\
\hline BTH & $42.06 \mathrm{~b}$ & $43.47 \mathrm{c}$ & $\begin{array}{c}24.33 \\
\mathrm{ab}\end{array}$ & $26.26 \mathrm{~b}$ & $314.50 \mathrm{a}$ & $315.33 \mathrm{ab}$ \\
\hline $\mathrm{W}$ & $*$ & $*$ & $*$ & $*$ & $*$ & $*$ \\
\hline $\mathrm{C}$ & $*$ & $*$ & $*$ & $*$ & $*$ & $*$ \\
\hline $\mathrm{W} \times \mathrm{C}$ & $\mathrm{ns}$ & $\mathrm{ns}$ & $\mathrm{ns}$ & $\mathrm{ns}$ & $\mathrm{ns}$ & $\mathrm{ns}$ \\
\hline
\end{tabular}

Data within columns followed by different letters are significantly different at $*=P \leq 0.05$; ns, no significant difference. WD: water deficit,WW: well-watered. S1= 2012/2013 season, S2= 2013/2014 season. Control= untreated plants; $\mathrm{SA}=$ Salicylic acid; $\mathrm{OX}=$ Oxalic acid $; \mathrm{BTH}=$ Benzothiadiazole

Egypt. J. Agron. 38, No. 2 (2016) 
TABLE 3. Effect of water treatments, chemical inducers on grain yield, straw yield and harvest index, respectively in 2012/2013 and 2013/2014 seasons.

\begin{tabular}{|c|c|c|c|c|c|c|}
\hline \multirow{2}{*}{$\begin{array}{l}\text { Treatments } \\
\text { Water treatments } \\
\text { (W) }\end{array}$} & \multicolumn{2}{|c|}{$\begin{array}{l}\text { Grain yield } \\
\left.\text { ton fad }^{-1}\right)\end{array}$} & \multicolumn{2}{|c|}{$\begin{array}{c}\text { Straw yield } \\
\left(\text { ton fad }^{-1}\right)\end{array}$} & \multicolumn{2}{|c|}{$\begin{array}{c}\text { Harvest index } \\
(\%)\end{array}$} \\
\hline & S1 & S2 & S1 & S2 & S1 & S2 \\
\hline WD & $2.76 \mathrm{~b}$ & $2.91 \mathrm{~b}$ & $4.76 \mathrm{~b}$ & $4.76 \mathrm{~b}$ & $36.48 \mathrm{~b}$ & $37.87 \mathrm{~b}$ \\
\hline WW & $3.16 \mathrm{a}$ & $3.43 \mathrm{a}$ & $5.42 \mathrm{a}$ & $5.53 \mathrm{a}$ & $36.82 \mathrm{a}$ & $38.16 \mathrm{a}$ \\
\hline \multicolumn{7}{|l|}{$\begin{array}{l}\text { Chemical inducers } \\
\text { (C) }\end{array}$} \\
\hline Control & $2.81 \mathrm{bc}$ & $3.24 \mathrm{c}$ & $4.93 \mathrm{c}$ & $5.32 \mathrm{c}$ & $36.02 \mathrm{c}$ & $37.86 \mathrm{~b}$ \\
\hline SA & $3.17 \mathrm{a}$ & $3.57 \mathrm{a}$ & $5.22 \mathrm{a}$ & $5.62 \mathrm{a}$ & $37.83 \mathrm{a}$ & $39.32 \mathrm{a}$ \\
\hline OX & $2.94 \mathrm{~b}$ & $3.45 \mathrm{~b}$ & $5.10 \mathrm{~b}$ & $5.57 \mathrm{~b}$ & $36.54 \mathrm{~b}$ & $38.66 \mathrm{ab}$ \\
\hline BTH & $2.92 \mathrm{~b}$ & $3.43 \mathrm{~b}$ & $5.11 \mathrm{~b}$ & $5.53 \mathrm{~b}$ & $36.37 \mathrm{~b}$ & $38.27 \mathrm{ab}$ \\
\hline $\mathrm{W}$ & $*$ & $*$ & $*$ & $*$ & $*$ & $*$ \\
\hline $\mathrm{C}$ & $*$ & $*$ & $*$ & $*$ & $*$ & $*$ \\
\hline $\mathrm{W} \times \mathrm{C}$ & ns & ns & ns & ns & $\mathrm{ns}$ & ns \\
\hline
\end{tabular}

Data within columns followed by different letters are significantly different at $*=P \leq 0.05$; ns, no significant difference. WD: water deficit,WW: well-watered. S1= 2012/2013 season, S2= 2013/2014 season. Control= untreated plants; $\mathrm{SA}=$ Salicylic acid; $\mathrm{OX}=$ Oxalic acid $; \mathrm{BTH}=$ Benzothiadiazole.

\section{Effect of treatments on grain quality content}

The effect of treatments on grain protein content is shown in Fig. 4. Water deficit posed negative effects on protein content compared to well-watered treatment in both seasons. Water deficit promote proteolytic degradation of Rubisco (ribulose-1,5-bisphosphate carboxylase/ oxygenase) protein (Lin \& Wang, 2002). Then, reduction in protein content under water deficit could be largely due to a decrease in Rubisco protein (Lin \& Wang, 2002).

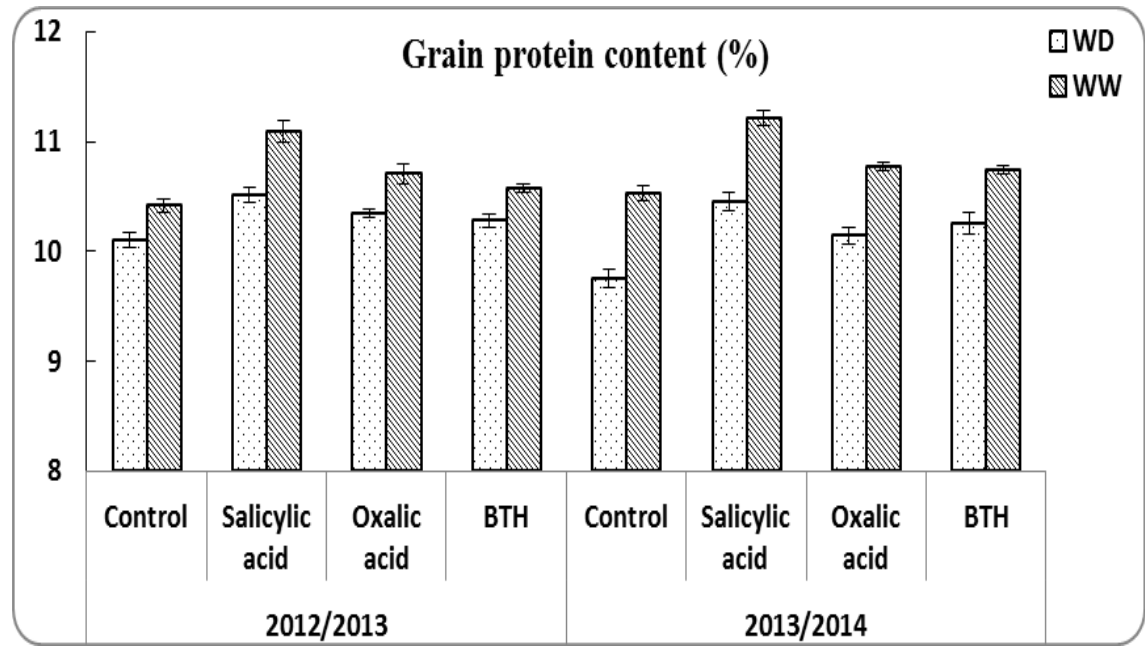

Fig. 4. Effect of water treatments (WW and WD) and chemical inducers (control, salicylic acid, oxalic acid and BTH) on grain protein content in 2012/2013 and 2013/2014 seasons. The data are the mean $\pm \mathrm{SE}$ of three replicates. WD: water deficit, WW: well-watered. 
Chemical inducers significantly improved grain protein content compared to control under water treatments in both seasons. The enzyme activity was increased by chemical inducers application in comparison with control. Chemical inducers are reduced damage to protein content and reduce the destructive effects of water deficit (Lin \& Wang, 2002 and Hafez \& Abdelaal, 2015). Salicylic acid had better effect and increased protein content more than oxalic acid and BTH when was imposed to water deficit in 2012-2013 and 20132014 seasons. Gunes et al. (2007) found that salicylic acid play an important role as endogenous signal molecule responsible for inducing abiotic stress tolerance in plants. They asserted that chemical inducer of salicylic acid increased protein content significantly both in water deficit and non-water deficit.

\section{Conclusion}

It was obvious that almost all the studied characters and biochemical parameters were significantly improved by chemical inducers application. Furthermore, it was clear that detrimental impacts of water deficit were significantly improved by chemical inducers. Among chemical inducers, salicylic acid ranked the first, followed by oxalic acid and BTH. It can be concluded that chemical inducers have a pivotal role in decreasing barley powdery mildew caused by Blumeria graminis f.sp. hordei (Bgh). All chemical inducers significantly up-regulated the antioxidant enzymes (CAT and POX) which in turn may be play a defense role against barley powdery mildew fungus. It is important to give much attention to further work on barley plants under a broader range of field conditions when suffering from water deficit to evaluate the possibility of using exogenous foliar spraying by chemical inducers for improving the productivity and reduce disease severity of barley.

Acknowledgement: The authors are appreciated of Plant Pathology and Biotechnology Laboratory and EPCRS Excellence Centre Staff, Dept. Agric. Botany, Fac. Agric., Kafrelsheikh University, Egypt.

\section{References}

A.O.A.C. (1980) Association of official agricultural chemists. "Official Method of Analysis", $13^{\text {th }}$ ed. A.O.A.C. Washington D.C.

Aebi, H.E. (1983) Catalase. "Methods of Enzymatic Analysis", $3^{\text {rd }}$ ed. pp 273-286. Verlag Chemie, Weinheim,

Ahmed, I.M, Cao, F.M., Zhang, X. and Zhang, G. (2013) Difference in yield and physiological features in response to drought and salinity combined stress during anthesis in Tibetan wild and cultivated barleys. PLOS ONE, 8(10), 1-14.

Anjum, S.A., Xie, X.Y., Wang, L.C., Saleem, M.F., Man, C. and Lei, W. (2011) Morphological, physiological and biochemical responses of plants to drought stress. Afr. J. Agr. Res. 6, 2026-2032.

Egypt. J. Agron. 38, No. 2 (2016) 
Bandurska, H., Stroinski, A. (2005) The effect of salicylic acid in barley response to water deficit. Acta Physiol. Plant. 27 (3B), 379-386.

Bremner, J.M., (1960) Determination of nitrogen in soil by the Kjeldahl method. J. Agr. Sci. 55, 11-37.

Cossania, C.M., Gustavo, A.S. and Roxana, S. (2012) Nitrogen and water use efficiencies of wheat and barley under a Mediterranean environment in Catalonia. Field Crops Res. 128, 109-118.

Duncan, B.D. (1955) Multiple ranges and multiple F-test. Biometri. 11, 1-42.

El-Seidy, E.H.E., Amer, Kh.A., El-Gammaal, A.A. and El-Shawy, E.E. (2013) Growth analysis and yield response of barley as affected by irrigation regimes. Egypt. J. Agron. 35 (1), 1-19.

Fayez, F.A. and Bazaid, S.A. (2014) Improving drought and salinity tolerance in barley by application of salicylic acid and potassium nitrate. J. of the Saudi Society of Agri. Sci. 13, 45-55.

Ghotbi-Ravandi, A.A., Shahbazi, M., Shariati, M. and Mulo, P. (2014) Effects of mild and severe drought stress on photosynthetic efficiency in tolerant and susceptible barley (Hordeum vulgare L.) genotypes. J. Agro. Crop. Sci. 200, 403-415.

Gomez, K.A. and Gomez, A.A. (1984) "Statistical Procedures for Agricultural Research". John Wiley and Sons, $2^{\text {nd }}$ ed. pp.180, New Yourk, U.S.A.

Görlach, J.,Volrath S., Knauf-Beiter, G., Hengy, G., Beckhove, U., Kogel, Kh., Oostendrop, M., Staub, T.E., Kessmann, H. and Ryals. J. (1996) Benzothiadiazole, a novel class of inducers of systemic acquired resistance, activates gene expression and disease resistance in wheat. Plant Cel,l 8, 629-643.

Gunes, A., Inal, A., Eraslan, F., Bacci, E.G. and Cicek, N. (2007) Salicylic acid induced changes of some physiological parameters sympomatic for oxidative stress and mineral nutrition in maize (Zea mays L.) grown under salinity. J. Plant Physiol., 164 (4), 726-732.

Hafez, E.M. and Kobata, T. (2012) The effect of different nitrogen sources from urea and ammonium sulfate on the spikelet number in Egyptian spring wheat cultivars on well watered pot soils. Plant Prod. Sci. 15 (4), 332-338.

Hafez, E.M. and Abdelaal, Kh.A.A. (2015) Impact of nitrogen fertilization levels on morphophysiological characters and yield quality of some maize hybrids (Zea mays L.). Egypt. J. Agron. 37(1),35 - 48.

Hafez, E.M. and Abou El-Hassan, W.H. (2015) Nitrogen and water utilization efficiency of barley subjected to desiccated conditions in moderately salt-affected soil. Egypt. J.Agron. 37(2), $231-249$.

Hafez, E.M. and Gharib, H.S. (2016) Effect of exogenous application of ascorbic acid on physiological and biochemical characteristics of wheat under water stress. Int. J. Plant Prod. 10 (4), 579-596. 
Hafez, E.M., Abou El-Hassan, W.H., Gaafar, I. A. and Seleiman, M. F. (2015) Effect of gypsum application and irrigation intervals on clay saline-sodic soil characterization, rice water use efficiency, growth, and yield. J. Agric. Sci. 7, (12), 208-219.

Hafez, E.M., Ragab, A.Y. and Kobata, T. (2014b) Water-use efficiency and ammonium-N source applied of wheat under irrigated and desiccated conditions. Int. J. Plant Soil Sci. 3 (10), 1302-1316.

Hafez, Y.M., Bacsó, R., Király, Z., Künstler, A. and Király, L. (2012) Up-regulation of antioxidants in tobacco by low concentrations of $\mathrm{H}_{2} \mathrm{O}_{2}$ suppresses necrotic disease symptoms. Phytopathol. 102, 848-856.

Hafez, Y.M., Mourad, R.Y., Mansour, M. and Abdelaal, Kh.A.A. (2014a) Impact of non traditional compounds and fungicides on physiological and biochemical characters of barely infected with Blumeria graminis f.sp. hordei under field condtition. Egyptian J. Biol. Pest Cont. 24 (2), 445-453.

Hammerschmidt, R., Nuckles, E.M. and Kuć, J. (1982) Association of enhanced peroxidase activity with induced systemic resistance of cucumber to Colletotrichum lagenarium. Physiol. Plant Pathol. 20 (1),73-82.

Harb, A., Awad, D. and Samarah, N., (2015) Gene expression and activity of antioxidant enzymes in barley (Hordeum vulgare L.) under controlled severe drought, J. of Plant Interactions, 10(1), 109-116.

Horsfall, J.G. and Cowling, E.B. (1978) Pathometry: the measurement of plant disease. In: "Plant Disease: An Advanced Treatise", Horsfall, J.G. and E.B. Cowling (Ed.), pp. 120-136. Vol. II. New York: Academic.

Jeon, M.W., Ali, M.B.E., Hahn, J. and Paek, K.Y. (2006) Photosynthetic pigments, morphology and leaf gas exchange during ex vitro acclimatization of micropropagated CAM Doritaenopsis plantlets under relative humidity and air temperature. Environ. Exp. Bot. 55, 183-194.

Kim, H.S., Hartman, G.L., Manandhar, J.B., Graef, G.L., Steadman, J.R. and Dier, B.W.(2000) Reaction of soybean cultivars to Sclerotia stem rots in field, greenhouse and laboratory evaluations. Crop Sci. 40, 665-669.

Krček, M., Slamka, P., Olšovská, K., Brestič, M. and Benčíková, M. (2008) Reduction of drought stress effect in spring barley (Hordeum vulgare L.) by nitrogen fertilization. Plant Soil Environ. 54, 7-13.

Lawton, K., Friedrich, L., Hunt, M., Weymann, K., Staub, T., Kessmann, H. and Ryals, J. (1996) Benzothiadiazole induces disease resistance in Arabidopsis by activation of the systemic acquired resistance signal transduction pathway. Plant $J$. 10, $71-82$.

Lin, G.S. and Wang, G.X. (2002) Doubled CO could improve the drought tolerance better in sensitive cultivars than in tolerant cultivars in spring wheat. Plant Sci. 163, 627-637.

Malencic, D.J., Vasic, D., Popovic, M. and Devic, D. (2004) Antioxidant systems in sunflower as affected by oxalic acid. Biologia Plantarum, 48, 243-247.

Egypt. J. Agron. 38, No. 2 (2016) 
Markwell, J., Osterman, J.C. and Mitchell, J.L. (1995) Calibration of the Minolta SPAD502 leaf chlorophyll meter. Photosynth Res. 46, 467-472.

Noctor, G., Mhamdi, A. and Foyer, C. (2014) Roles of reactive oxygen metabolism in drought: not so cut and dried. Plant Physiol. 164, 1636-1648.

Omwamba, M., Li, F., Sun, G. and Hu, Q. (2013) Antioxidant effect of roasted barley (Hordeum vulgare L.) grain extract towards oxidative stress in vitro and in vivo. Food and Nutrition Sciences, 4, 139-146.

Pecio, A. and Wach, D. (2015) Grain yield and yield components of spring barley genotypes as the indicators of their tolerance to temporal drought stress. Polish J. Agronomy, 21, 19-27

Pirasteh-Anosheh, H., Emam, Y. and Sepaskhah, A.R. (2015) Improving barley performance by proper foliar applied salicylic-acid under saline conditions. International Journal of Plant Production, 9 (3), 467-486.

Samarah, N.H. (2005) Effects of drought stress on growth and yield of barley. Agronomy for Sustainable Development, 25 (1),145-149.

Wu, F.Z., Bao, W.K., Li, F.L. and Wu, N. (2008) Effects of water stress and nitrogen supply on leaf gas exchange and fluorescence parameters of Sophora davidii seedlings. Photosynthetica, 46 (1), 40-48.

Zheng, G.Y., Zhao, R.L. and Peng, X. (1999) Oxalate-induced resistance of Muskmelon to WMV-2. Chinese Science Bulletin, 44, 1794-1797.

(Received 16 / 6 / 2016;

accepted 7 / 9 / 2016) 


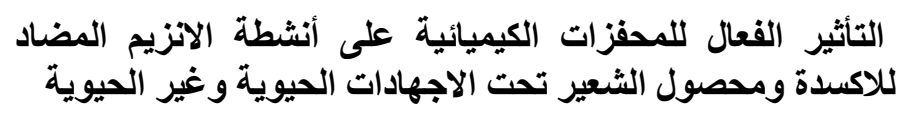

عماد الاين ماهر حافظ و ياسر محمد حافظ*

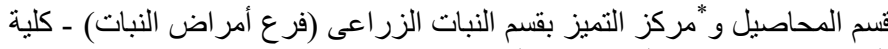
الزراعة - جامعة كفر الثيخ ـ كفر الثنيخ - مصر.

الهدف من هذا البحث هو دراسة تأثير المحفزات الكيميائية على دليل

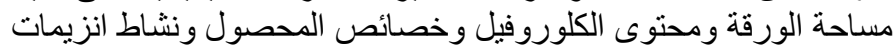

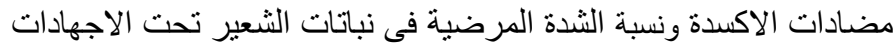

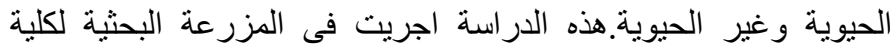

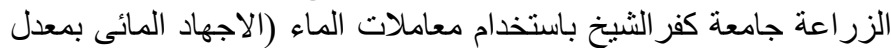

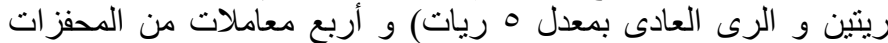

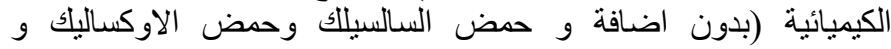

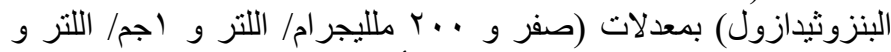

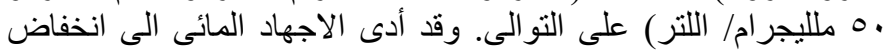

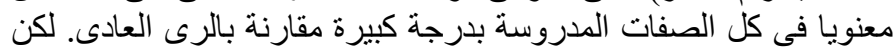

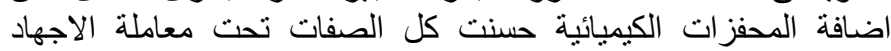

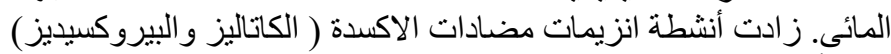

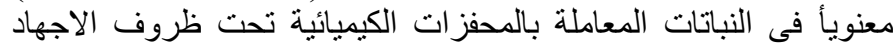

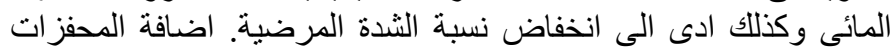

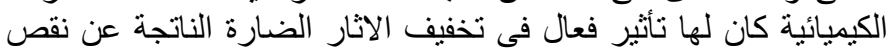

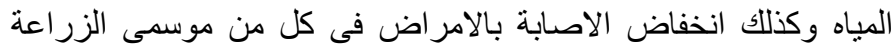

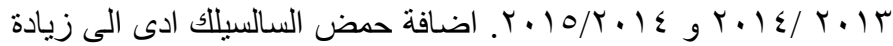

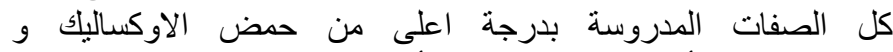

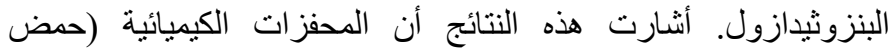

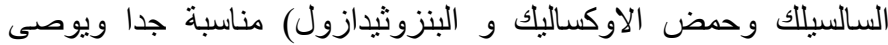
باستخدامها لزيادة الانتاجية تحت ظروف الئزئ الاجهادات الحيوية وغير ويري

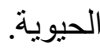

